\title{
Ancaman Masuknya Virus Penyakit Mulut dan Kuku Melalui Daging Ilegal di Entikong, Perbatasan Darat Indonesia dan Malaysia
}

\author{
The Threat of Foot and Mouth Disease Virus by the Ilegal Meat Circulation \\ at Entikong, a Borderland between Indonesia and Malaysia
}

\author{
Risma JP Silitonga ${ }^{1}$, Retno Damajanti Soejoedono ${ }^{2}$, Hadri Latif ${ }^{2}$, Etih Sudarnika ${ }^{2}$ \\ ${ }^{1}$ Badan Karantina Pertanian \\ Jalan Harsono RM Nomor 3, Ragunan, Pasar Minggu, Jakarta 12550 \\ ${ }^{2}$ Departemen Ilmu Penyakit Hewan dan Kesehatan Masyarakat Veteriner, \\ Fakultas Kedokteran Hewan, Institut Pertanian Bogor \\ Jl. Agatis, Kampus IPB Darmaga Bogor 16680 \\ Email: rismajps.21@gmail.com
}

\begin{abstract}
This study was aimed to analyze the risk of FMD virus to enter Indonesia by the presence of illegal meat at Entikong, a borderland between Indonesia and Malaysia. The primary datas were collected using questionnaires method to collect expertise, in-depth interviews, and direct field observations. Secondary datas were obtained from scientific publications and articles or unpublished datas (statistics, goverment documents and reports). The respondents were choosen by purposive sampling. The circulating illegal meat was possibly originate from different countries, including FMD-endemic countries/zones such as Peninsular Malaysia, Thailand, India and even unidentified countries/zones according to our respondends. The types of illegal meat such as frozen deglanded bonein-meat and frozen deglanded offal that enter Entikong carry the risk of becoming a source of FMD infection. Based on the entry route, delivery frequency, and meat volume, ilegal meat was possibly also entered into Indonesia using non-vehicular transportation. These conditions indicated that the entrance of illegal meat could pose risk of the FMD virus entry to Indonesia, especially at the borderland between Indonesia and Malaysia at Entikong. It is highly recommended to apply strict inspection at the border entraces and increase collaboration with related institutions to prevent the entrance of illegal meat and to reduce the entry risk of FMD virus.
\end{abstract}

Keywords: border, Entikong, FMD, illegal meat

\begin{abstract}
Abstrak
Penelitian ini bertujuan untuk menganalisis keberadaan daging ilegal di perbatasan darat IndonesiaMalaysia sebagai ancaman risiko masuknya virus PMK ke wilayah Indonesia. Data primer diambil menggunakan teknik pengumpulan pendapat pakar dengan kuisioner, wawancara mendalam (in-depth interview) dan pengamatan langsung di lapangan. Data sekunder diperoleh dari publikasi ilmiah dan tulisan atau data yang tidak dipublikasi (statistik, dokumen dan laporan dari instansi berwenang). Penentuan responden secara purposive sampling. Hasil studi menunjukkan bahwa daging ilegal diperkirakan berasal dari berbagai negara termasuk dari negara/zona yang berstatus endemis PMK seperti Semenanjung Malaysia, Thailand, India dan negara/zona yang dinyatakan tidak diketahui oleh responden. Jenis daging ilegal yang masuk ke Entikong berisiko sebagai sumber infeksi PMK seperti daging beku bertulang tanpa limfoglandula dan jeroan beku tanpa limfoglandula. Berdasarkan jalur dan frekuensi pengangkutan, perkiraan volume pemasukan daging ilegal menunjukkan kemungkinan daging masih bisa lolos melalui jalur non-kendaraan. Kondisi-kondisi tersebut mengindikasikan bahwa pemasukan daging ilegal dapat sebagai ancaman risiko masuknya virus PMK ke Indonesia khususnya di perbatasan darat IndonesiaMalaysia, Entikong. Perlu dilakukan upaya pencegahan untuk mengurangi ancaman risiko yaitu dengan melakukan pengawasan yang lebih ketat di pintu-pintu pemasukan dengan berkoordinasi lintas instansi di perbatasan untuk bersama-sama mencegah pemasukan daging ilegal.
\end{abstract}

Kata kunci: daging ilegal, Entikong, PMK, perbatasan 


\section{Pendahuluan}

Indonesia telah dinyatakan bebas Penyakit Mulut dan Kuku (PMK) sejak tahun 1986 (Ditkeswan, 2009). Berbagai upaya telah dilakukan untuk tetap mempertahankan status bebas tersebut. Salah satunya adalah dengan melakukan importasi hewan dan produknya hanya dari negara/zona bebas PMK. Malaysia merupakan negara tetangga Indonesia dengan status belum seluruhnya bebas PMK, masih ada beberapa zona dengan kasus PMK. Salah satu daerah yang berisiko terhadap PMK karena berbatasan secara langsung melalui darat dengan Malaysia adalah Entikong di Kalimantan Barat.

Daging ilegal saat ini masih ditemukan di daerah perbatasan-perbatasan darat antara Indonesia dan Malaysia. Pada tahun 2014, Stasiun Karantina Pertanian Kelas I Entikong telah menahan dan memusnahkan sebanyak $504 \mathrm{~kg}$ daging sapi beku, $300 \mathrm{~kg}$ daging kerbau beku, $20 \mathrm{~kg}$ daging sapi dingin bertulang dan pada tahun 2015 sebanyak 480 daging sapi beku bertulang (SIKAWAN, 2015).

Menurut Harada et al. (2007), PMK sangat menular ke hewan berkuku belah. Transmisi dilaporkan terjadi melalui kontak langsung dengan hewan terinfeksi, aerosol, semen, produk makanan, dan fomites. Morbiditas penyakit ini sangat tinggi tetapi mortalitasnya rendah dan sangat cepat menular (highly contagious) (Rushton dan Knight-Jones, 2013).

Daging yang mengandung virus PMK aktif dapat menjadi risiko munculnya PMK, terutama jika daging terkontaminasi diberikan sebagai pakan babi. Sebagaimana yang terjadi pada wabah PMK di Great Britain tahun 2001, diperkirakan karena pemberian pakan babi dari sisa makanan yang mengandung daging. Pemberian pakan jenis ini, diperkirakan sejak tahun 2000 terhadap 82.000 babi (1.4\% populasi babi) di Great Britain (Hartnett et al. 2007).

Berdasarkan kondisi-kondisi tersebut, maka perlu dikaji keberadaan daging ilegal di perbatasan Entikong, yang merupakan daerah yang berbatasan langsung dengan Malaysia sebagai negara belum bebas PMK. Dengan demikian, tujuan penelitian ini adalah untuk menganalisis keberadaan daging ilegal di daerah perbatasan Entikong sebagai ancaman risiko masuknya virus PMK ke wilayah Indonesia. Hasil kajian ini diharapkan dapat menjadi bahan kebijakan pemerintah untuk menentukan langkah-langkah pencegahan masuknya virus PMK melalui daging ilegal atau sebagai bahan kebijakan dalam pengaturan lalu lintas daging dan produknya di daerah perbatasan negara.

\section{Materi dan Metode}

Penelitian dilakukan di daerah perbatasan darat Indonesia dan Malaysia (Kecamatan Entikong, Kabupaten Sanggau, Provinsi Kalimantan Barat) yaitu di Pos Pemeriksaan Lintas Batas (PPLB) Entikong. Pengolahan data dilakukan di Laboratorium Epidemiologi Fakultas Kedokteran Hewan Institut Pertanian Bogor.

Data yang digunakan sebagai pengubah input dalam penelitian ini meliputi data primer dan data sekunder. Data primer diambil dengan menggunakan kuisioner, wawancara mendalam (in-depth interview) dan pengamatan langsung di lapang. Data sekunder diperoleh dari publikasi ilmiah dan tulisan atau data yang tidak dipublikasi (statistik, dokumen dan laporan dari instansi berwenang).

Responden pelintas batas adalah orang yang melintas di PPLB Entikong dengan berjalan kaki. Responden penumpang adalah semua orang yang melintas melewati PPLB Entikong dengan menggunakan kendaraan, dan pada saat data ini diminta para penumpang sedang melakukan pelaporan di loket imigrasi. Responden pengemudi adalah semua orang yang mengemudikan kendaraan bermotor, meliputi kendaraan umum maupun kendaraan pribadi.

Penentuan responden terkait dengan alur pemasukan daging ilegal dari Malaysia ke Entikong tersaji pada Tabel 1. 
Tabel 1. Daftar responden penelitian.

\begin{tabular}{lcl}
\hline \multicolumn{1}{c}{ Responden } & Jumlah & \multicolumn{1}{c}{ Keterangan } \\
\hline Pelintas batas dan penumpang & 57 & $\begin{array}{l}\text { Purposive sampling atau pemilihan secara sengaja } \\
\text { dengan mempertimbangkan pekerjaan dan kesediaan } \\
\text { responden untuk diwawancara }\end{array}$ \\
Pengemudi & 41 & $\begin{array}{l}\text { Purposive sampling atau pemilihan secara sengaja dengan } \\
\text { mempertimbangkan jenis kendaraan yang dikemudikan } \\
\text { dan kesediaan responden untuk diwawancara }\end{array}$ \\
Pemilik warung/rumah makan & 3 & $\begin{array}{l}\text { Purposive sampling atau pemilihan secara sengaja } \\
\text { dengan mempertimbangkan jenis menu yang disajikan } \\
\text { dan kesediaan responden untuk diwawancara }\end{array}$ \\
Pedagang daging & 6 & $\begin{array}{l}\text { Pemilihan menurut keterwakilan pedagang skala kecil, } \\
\text { sedang dan besar di wilayah Perbatasan Entikong }\end{array}$ \\
Peternak babi & 2 & $\begin{array}{l}\text { Pemilihan menurut keterwakilan peternak babi di wilayah } \\
\text { Perbatasan Entikong }\end{array}$ \\
Peternak ruminansia & 2 & $\begin{array}{l}\text { Pemilihan menurut keterwakilan peternak ruminansia di } \\
\text { wilayah Perbatasan Entikong }\end{array}$ \\
Petugas Karantina Pertanian & 7 & $\begin{array}{l}\text { Purposive sampling atau pemilihan secara sengaja } \\
\text { dengan mempertimbangkan profesi/pekerjaannya dan } \\
\text { kesediaan responden untuk diwawancara } \\
\text { Petugas PPLB (selain petugas Karantina } \\
\text { pelabuhan, kepolisian, TNI) }\end{array}$ \\
\hline
\end{tabular}

\section{Hasil dan Pembahasan}

Definisi daging ilegal dalam penelitian ini adalah daging ruminansia segar yang tidak disertai dengan sertifikat kesehatan/sanitasi, tidak dilaporkan dan diserahkan ke petugas karantina serta tidak melalui tempat-tempat yang sudah ditetapkan. Hal ini sesuai dengan Pasal 5 Undang-Undang Republik Indonesia Nomor 16 Tahun 1992 tentang Karantina Hewan, Ikan dan Tumbuhan bahwa "setiap media pembawa hama dan penyakit hewan karantina yang dimasukkan ke dalam wilayah negara Republik Indonesia wajib dilengkapi sertifikat kesehatan dari negara asal dan negara transit bagi hewan, bahan asal hewan dan hasil bahan asal hewan, melalui tempat-tempat pemasukan yang telah ditetapkan dan dilaporkan dan diserahkan kepada petugas karantina di tempat-tempat pemasukan untuk keperluan tindakan karantina" (Deptan, 2004). Artinya bahwa daging ilegal tersebut tidak dapat dijamin sanitasinya sehingga kemungkinannya masih memiliki risiko atau bahaya.

\section{Negara/zona Asal dan Tempat Perolehan Daging Ilegal}

Daging ilegal yang masuk ke Entikong berasal dari beberapa negara/zona. Berturut-turut negara/ zona asal daging ilegal berdasarkan persentase paling banyak yang pernah dibawa oleh penumpang yaitu 1) negara/zona yang dinyatakan tidak diketahui oleh responden penumpang; 2) Australia, 3) Serawak, 4) India, 5) Semenanjung Malaysia, 6) Brunei Darussalam, dan 7) Thailand (Gambar 1).

Gambar 1 menjelaskan bahwa daging ilegal yang masuk melalui Entikong berasal dari negara/ zona bebas PMK dan negara/zona endemis PMK. Penentuan status dan situasi penyakit negara/zona asal berdasarkan disease timelines Office International 


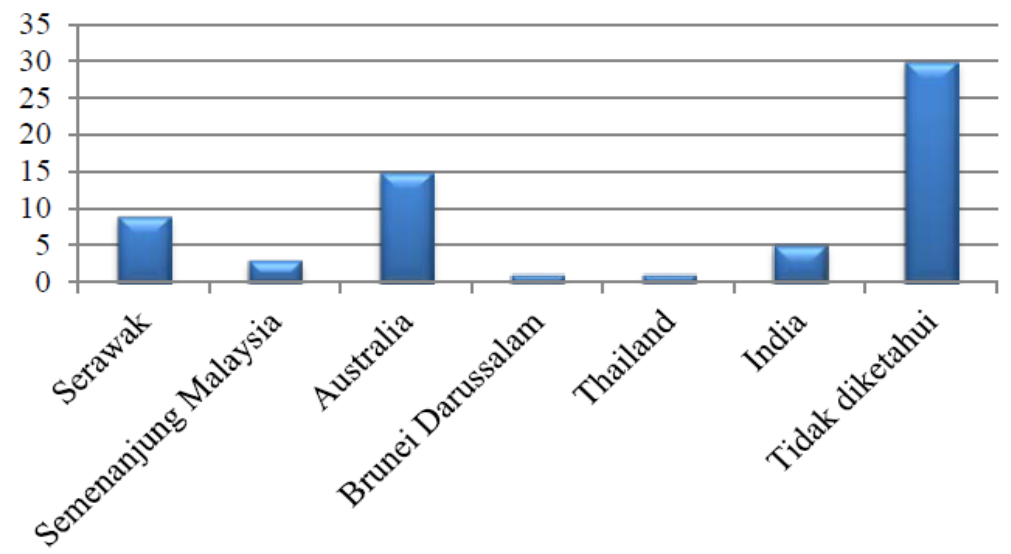

Gambar 1. Negara/zona asal daging ilegal berdasarkan informasi 64 responden.

des Epizooties (OIE, 2015). Negara/zona asal daging ilegal yang berstatus endemis PMK yaitu Semenanjung Malaysia, Thailand, India dan negara/ zona yang dinyatakan tidak diketahui oleh responden. Jumlah responden yang menyatakan daging berasal dari negara/zona endemis PMK diperkirakan sebanyak $65 \%$ dari 64 responden, sedangkan daging ilegal yang masuk melalui Entikong berasal dari negara/zona bebas PMK diperkirakan sebanyak 35\%. Kondisi ini menggambarkan bahwa daging ilegal yang masuk sebagian besar berasal dari negara/zona endemis PMK, sehingga merupakan suatu peluang risiko terhadap ancaman masuknya PMK ke Indonesia.

Daging ilegal yang masuk melalui Entikong diperoleh atau dibeli dari berbagai tempat yaitu kios/ kedai, jasa pengiriman/personal, "toke" atau "bos" daging, pasar, supermarket, dan gudang (Gambar 2). "Toke" atau "bos" adalah orang yang pekerjaannya sebagai penjual daging dalam partai besar maupun kecil.

Tidak ada informasi yang menyatakan bahwa daging berasal dari rumah pemotongan hewan atau melihat langsung hewan disembelih. Jasa pengiriman/ personal adalah orang yang jasanya mengirimkan daging melalui kendaraan yang akan melintas melalui Entikong atau disebut juga sebagai agen pengiriman.

Gambar 2 menjelaskan bahwa sebagian besar daging ilegal diperoleh dari pasar, dan berturut-turut diperoleh dari supermarket, "toke" atau "bos" daging, jasa pengiriman/personal, kios/ kedai dan gudang sebelum diangkut atau dibawa masuk melalui Entikong. Tempat perolehan daging yang paling berisiko kemungkinannya adalah pasar, namun karena sumbernya sulit untuk ditelusuri sehingga mungkin bisa dari berbagai tempat. Selain itu kemungkinan daging terkontaminasi lebih besar terjadi di pasar.
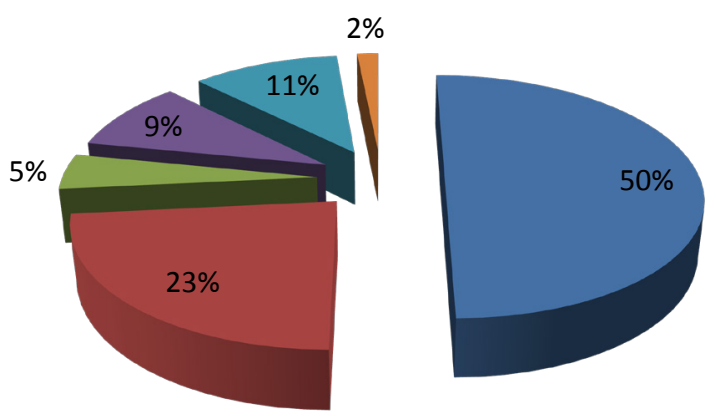

- Pasar

- Supermarket

Kios/kedai

- Jasa pengiriman/personal

- "Toke" atau "bos" daging

Gudang

Gambar 2. Persentase tempat perolehan daging ilegal berdasarkan informasi 64 responden. 


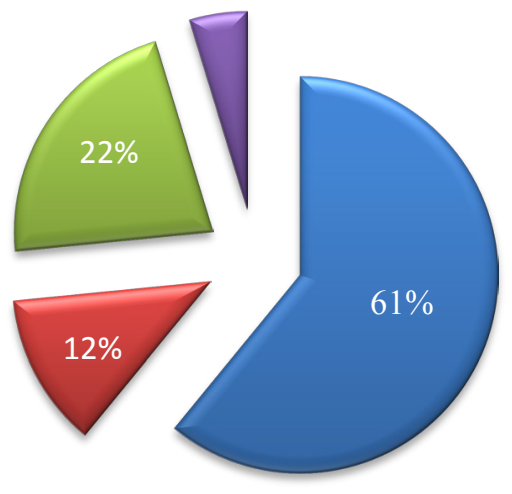

$\square$ daging beku, tanpa tulang, tanpa limfoglandula (frozen meat, deboned, deglanded)

$\square$ daging beku bertulang, tanpa limfoglandula (frozen meat bone in, deglanded)

$\square$ daging dingin tanpa tulang, tanpa limfoglandula (chilled meat, deboned, deglanded)

Gambar 3. Persentase jenis daging ilegal yang masuk melalui Entikong berdasarkan informasi 64 responden.

\section{Jenis dan Kemasan Daging Ilegal}

Jenis daging ilegal yang masuk melalui Entikong yaitu daging beku tanpa tulang dan limfoglandula (frozen deboned deglanded meat), daging beku bertulang tanpa limfoglandula (frozen deglanded meat bone), daging dingin tanpa tulang dan limfoglandula (chilled deboned deglanded meat) serta jeroan beku tanpa limfoglandula (frozen deglanded offal) (Gambar 3). Jenis daging ilegal sebagai sumber infeksi PMK yang masuk ke Entikong diperkirakan sekitar $12 \%$ daging beku bertulang tanpa limfoglandula dan 5\% jeroan beku tanpa limfoglandula. Persentase jenis daging sebagai sumber infeksi PMK jauh lebih sedikit dibandingkan dengan persentase jenis daging yang dianggap aman atau tidak sebagai sumber infeksi PMK. Namun, meskipun jenis daging ilegal yang aman atau tidak sebagai sumber infeksi PMK kondisi tersebut tidak dapat diabaikan. Studi literatur yang dilakukan oleh Ryan et al. (2008) menyatakan bahwa virus PMK masih terdeteksi selama 4 bulan di dalam frozen liver yang berasal dari hewan viremia.

Menurut Paton et al. (2010), syarat daging yang direkomendasikan OIE untuk diperdagangkan dari negara/zona endemis PMK yaitu harus berasal dari karkas tanpa tulang (deboned carcasses) yang kelenjar getah bening utamanya telah dihilangkan (deglanded). Sebelum deboning, karkas harus dilayukan pada suhu di atas $2^{\circ} \mathrm{C}$ minimal selama 24 jam dan $\mathrm{pH}$ harus di bawah 6.0 saat diuji di bagian tengah kedua otot longissimus dorsi.
Kemasan daging ilegal berupa plastik tanpa merk, karton tanpa merk, styrofoam, karton dengan merk, plastik dengan merk. Daging yang kemasannya berupa plastik dan karton tanpa merk, kemungkinan asal-usul daging tidak jelas diketahui karena identitas produsen daging tidak tercantum sehingga tidak dapat ditelusuri. Daging yang dikemas seperti ini kemungkinan diperoleh dalam bentuk curah yang tidak terjamin kualitasnya. Hasil pengamatan langsung terhadap kuli pikul/dorong yang sedang membawa daging, kemasan daging yang diangkut berupa plastik di bagian dalam dan karton di bagian luar. Namun, ada juga yang menggunakan plastik tanpa dikemas lagi dengan karton pada bagian luarnya. Daging yang dijual di toko daging kemasannya berupa plastik, pada kemasannya tertera tempat produsen dari India serta tercantum dengan jelas jenis daging pada kemasannya, sehingga jenis daging dengan kemasan seperti ini kemungkinan dapat ditelusuri unit usahanya.

\section{Jalur dan Frekuensi Pengangkutan Daging Ilegal}

Jalur atau rute pengangkutan daging ilegal melalui PPLB Entikong dibagi menjadi dua kelompok pengangkutan yaitu menggunakan kendaraan dan nonkendaraan. Pengangkutan dengan kendaraan dilakukan dengan bis besar, bis sedang, minibus, mobil boks, van (angkutan umum jarak dekat Malaysia yang=sejenis angkutan kota), sedan dan sejenisnya. Pengangkutan menggunakan non-kendaraan yaitu dengan dipikul atau dipanggul, ditenteng dan didorong dengan gerobak/ 
Tabel 2. Jalur atau rute pengangkutan daging ilegal melalui Entikong.

\begin{tabular}{lcc}
\hline \multicolumn{1}{c}{ Cara mengangkut daging } & \multicolumn{2}{c}{ Jumlah responden } \\
& $\begin{array}{c}\text { Pelintas batas dan } \\
\text { penumpang }\end{array}$ & Pengemudi \\
\hline Menggunakan kendaraan: & 1 & - \\
- sedan & 11 & 11 \\
- minibus & 6 & 6 \\
- mobil boks & 6 & 1 \\
- angkutan penumpang jarak dekat (van) & 25 & 1 \\
- bis besar & - & 1 \\
- bis sedang & - & 16 \\
- lain-lain (ambulance) & \multicolumn{2}{|}{} \\
Menggunakan non-kendaraan: & 5 & - \\
- dipikul/dipanggul & 5 & - \\
- ditenteng & 2 & \\
- didorong dengan gerobak/kereta dorong & \multicolumn{2}{c}{} \\
\hline
\end{tabular}

kereta dorong. Proporsi daging diangkut dengan kendaraan dan non-kendaraan tersaji pada Tabel 2.

Hasil studi menunjukkan bahwa pengangkutan daging ilegal sebagian besar menggunakan kendaraan umum dibanding dengan menggunakan kendaraan pribadi. Pengangkutan daging menggunakan non-kendaraan jumlahnya lebih sedikit. Namun pengangkutan dengan cara memikul/memanggul maupun dengan gerobak/kereta dorong tersebut dilakukan secara berulang-ulang oleh kuli panggul/ pikul/dorong. Perkiraan berat daging yang dipikul sekitar 10-20 kg per kali angkut/pikul. Apabila setiap orang kuli panggul/pikul/dorong pulang pergi sebanyak 4 kali, maka berat daging yang diangkut sekitar 40-80 kg per orang. Pengangkutan seperti ini biasanya dilakukan secara berkelompok 2-5 orang atau biasa disebut dengan istilah "borongan".

Pada umumnya tujuan pelintas batas bepergian atau datang dari Malaysia karena alasan pekerjaan. Hasil studi menginformasikan, pekerjaan pelintas batas yaitu sebagai buruh pikul/dorong, pengemudi, pedagang, petani, pegawai swasta, guru agama, penjahit dan ibu rumah tangga. Berdasarkan banyaknya melintas (frekuensi), maka pelintas batas dibagi menjadi 3 kelompok yaitu sering, jarang dan tidak tentu. Kelompok sering adalah pelintas batas yang melintas minimal satu kali dalam satu minggu atau hampir setiap hari. Kelompok jarang yaitu pelintas batas yang melintas minimal satu kali dalam satu bulan, sedangkan yang dimaksud dengan kelompok tidak tentu yaitu pelintas batas yang melintas tidak tentu waktunya (tidak termasuk dalam kelompok sering dan jarang).

Jasa pengangkut atau kuli panggul/pikul/ dorong mengangkut daging ilegal tidak melewati pintu resmi pemasukan di PPLB Entikong. Mereka menyelinap, sembunyi dan menghindar dari pengawasan petugas. Hal ini dilakukan dalam situasi hiruk-pikuk para pelintas batas, pada saat ada kendaraan melintas (ramai) dan saat para petugas sibuk melakukan pemeriksaan, para kuli panggul/ pikul/dorong menyelinap di pintu-pintu masuk PPLB Entikong. Mereka melewati pinggir-pinggir pagar PPLB Entikong, seperti layaknya pejalan kaki biasa. Mereka memanggul barang memakai kain gendongan, menggunakan gerobak dorong dan ada pula yang menenteng barang menggunakan kantong plastik. 


\section{Perkiraan Volume Pemasukan Daging Ilegal}

Berat daging yang diangkut dengan kendaraan maupun non-kendaraan rata-rata sekitar $1-50 \mathrm{~kg}$. Daging yang diangkut dengan kendaraan sebagian besar beratnya lebih dari $50 \mathrm{~kg}$, yang dipikul/didorong dengan berjalan kaki sekitar 10-20 kg. Daging yang diangkut untuk konsumsi sendiri beratnya kurang dari $10 \mathrm{~kg}$ dan daging untuk dijual kembali atau diolah beratnya sekitar 10-50 kg. Daging diangkut/dibawa ke Entikong oleh pemilik daging atau jasa pengirim/ pengangkut daging. Ibu rumah tangga merupakan sebagian besar pemilik atau pengangkut daging, selain itu mereka juga sebagai pedagang campuran, pedagang daging eceran, penjual makanan, kuli pikul/panggul/dorong.

Sebagian besar tujuan membawa/ mengangkut daging adalah untuk dikonsumsi sendiri. Kemungkinan alasan responden memilih tujuan membawa masuk daging untuk konsumsi sendiri adalah supaya menghindari ketentuan/peraturan yang berlaku atau dianggap tidak melanggar, khususnya mereka yang mengangkut daging dengan cara dipikul/ dipanggul/didorong. Menurut informasi petugas PPLB, diperkirakan jumlah daging ilegal yang masuk sekitar 100-400 kg perminggu. Jumlah daging yang masuk tergantung musim pesta atau perayaan adat masyarakat di sekitar perbatasan yang disebut dengan "gawai".

Berdasarkan hasil studi yaitu negara/zona asal daging, jenis dan kemasan daging, jalur/rute dan frekuensi pengangkutan, pengawasan petugas perbatasan serta perkiraan volume pemasukan daging ilegal maka diperoleh gambaran keberadaan daging ilegal di perbatasan Entikong. Beberapa kondisi yang paling berperan menyatakan bahwa pemasukan daging ilegal di perbatasan darat Indonesia-Malaysia dapat sebagai ancaman risiko terhadap munculnya PMK karena terdapat daging berasal dari negara/ zona endemis PMK. Menurut OIE dalam Paton et al. (2010) terdapat jenis daging ilegal yang tidak aman yaitu daging beku bertulang tanpa limfoglandula (frozen meat bone in deglanded) dan jeroan beku tanpa limfoglandula (frozen offal deglanded). Oleh karena itu, pencegahan terhadap pemasukan daging ilegal harus dilakukan agar kemungkinan penyebaran penyakit dari daging ilegal tidak terjadi. Hal tersebut sesuai dengan pendapat Valarcher et al. (2008) dan Rweyemamu et al. (2008), bahwa pada umumnya kecenderungan penyebaran virus PMK serotipe $\mathrm{O}$ (PanAsia) di daerah enzootic biasanya mengikuti gerakan legal dan ilegal dari hewan yang terinfeksi, sedangkan penyebaran ke daerah bebas lebih terkait dengan gerakan ilegal dari produk hewan.

Studi ini secara keseluruhan menyimpulkan bahwa pemasukan daging ilegal di perbatasan Entikong dapat sebagai ancaman terhadap masuknya virus PMK ke Indonesia, sehingga perlu dilakukan upaya pencegahan dan tindakan untuk mengurangi risiko. Pengawasan dan pemeriksaan yang lebih intensif harus dilakukan oleh petugas-petugas di perbatasan dengan koordinasi lintas instansi sehingga bersama-sama mencegah pemasukan daging ilegal maupun produk ilegal lainnya ke Indonesia. Selain itu, perlu dilakukan sosialisasi yang berkelanjutan serta penegakan hukum terhadap setiap orang atau masyarakat yang tidak mematuhi peraturan perundang-undangan.

\section{Kesimpulan}

Penelitian ini dapat disimpulkan bahwa daging ilegal diperkirakan berasal dari berbagai negara termasuk dari negara/zona yang berstatus endemis PMK seperti Semenanjung Malaysia, Thailand, India dan negara/zona yang dinyatakan tidak diketahui oleh responden. Jenis daging ilegal yang masuk ke Entikong berisiko sebagai sumber infeksi PMK seperti daging beku bertulang tanpa limfoglandula dan jeroan beku tanpa limfoglandula. Berdasarkan jalur dan frekuensi pengangkutan, perkiraan volume 
pemasukan daging ilegal menunjukkan kemungkinan daging masih bisa lolos melalui jalur non-kendaraan. Kondisi-kondisi tersebut mengindikasikan bahwa pemasukan daging ilegal dapat sebagai ancaman risiko masuknya virus PMK ke Indonesia khususnya di perbatasan darat Indonesia-Malaysia, Entikong.

\section{Ucapan Terima Kasih}

Penelitian ini didukung oleh beasiswa Sumber Daya Manusia Kementerian Pertanian. Penulis mengucapkan terima kasih kepada Badan Karantina Pertanian yang telah memfasilitasi penelitian ini.

\section{Daftar Pustaka}

Departemen Pertanian Republik Indonesia. (2004) Undang-Undang Republik Indonesia Nomor 16 Tahun 1992 tentang Karantina Hewan, Ikan dan Tumbuhan. Jakarta (ID): Deptan.

Direktorat Kesehatan Hewan, Direktorat Jenderal Peternakan, Departemen Pertanian. (2009) Kesiagaan Darurat Veteriner Indonesia. Seri: Penyakit Mulut dan Kuku (Kiat Vetindo PMK). Edisi 2.2. Jakarta (ID): Ditkeswan.

Harada ,Y, Lekcharoensuk P, Furuta T, and Taniguchi T. (2015) Inactivation of foot-and-mouth disease virus by commercially available disinfectants and cleaners. Biocon. Sci. 20(3):205-208.

Hartnett, E., Adkin A, Seaman, M., Cooper J., Watson E, Coburn H, England T, Marooney C, Anthony C, and Wooldridge M. (2007) A quantitative assessment of the risk from illegally imported meat contaminated with foot and mouth disease virus to Great Britain. Risk. Analysis. 27(1):187-202. doi: 10.1111/j.15396924.2006.00869.x.

Office Internationaldes Epizooties. (2015) WorldAnimal Health Information Database (WAHIS Interface). [internet]. [diacu 2015 Oktober 15]. Tersedia dari : http:/www.oie.int/wahis_2/public/wahid. php/Countryinformation/Countrytimelines.Paris (FR): World Organization for Animal Health.
Paton D.J, Sinclair M, and Rodriguez R. (2010) Qualitative assessment of the commodity risk for spread of foot-and-mouth disease associated with international trade in deboned beef. Transbound. Emerg. Dis.57:115-134.

Rushton J, and Knight-Jones T.J.D. (2013) The impact of foot-mouth-disease. Rev. sci. tech. Off. int. Epiz. 1:1-27.

Rweyemamu M, Roeder P, Mackay D, Sumption $\mathrm{K}$, Brownlie J, Leforban Y, and Valarcher J.F. (2008) Epidemiological patterns of footand-mouth disease worldwide. Transbound. Emerg. Dis. 55:57-72.

Ryan E.D, Mackay D, and Donaldson A. (2008) Foot-and-mouth disease virus concentrations in products of animal origin. Transbound. Emerg. Dis. 55:89-98.

Sistem Karantina Hewan. (2015) Badan Karantina Pertanian. [internet]. [diacu 2015 Nopember 6]. Tersedia dari :http://www.karantina.deptan. go.id/. Jakarta (ID).

Valarcher J.F, Leforban Y, Rweyemamu M, Roeder P.L, Gerbier G, Mackay D.K, Sumption K.J, Paton D.J, and Knowles N.J. (2008) Incursions of footand-mouth disease virus into Europe between 1985 and 2006. Transbound. Emerg. Dis. 55:14 34. 